\title{
Residents' perceptions of the role and management of green spaces to provide cultural ecosystem services in Dhaka, Bangladesh
}

\author{
Rumana Sultana ${ }^{1}$ and Samiya Ahmed Selim ${ }^{1}$
}

\begin{abstract}
Ongoing rapid urbanization and socio-environmental changes are posing challenges to proper urban management. Cultural ecosystem services (CES) offered by urban green spaces play a crucial role in the well-being of urban residents through ecosystems' non-material benefits. However, these services, especially from the residents' perspective, are often neglected in urban management strategies because of their intangible nature, particularly in the Global South. In this study, conducted in Dhaka, Bangladesh, we investigated residents' perceptions of the importance of CES offered by green spaces and how green space should be managed. As a methodological tool, we used a questionnaire-based stated preference method where non-monetary statements were the basis. Questions in the survey included respondents' social background and visiting frequency to green space, perceived importance of CES and green space, and perceptions about the management of green space. We analyzed 405 questionnaires using descriptive and inferential statistics. Our results indicate that rooftop gardens and green parks are considered the most important areas that provide CES, and among different types of CES (i.e., recreation, aesthetic, mental satisfaction, social relations), recreation is considered the most important. The high importance respondents place on the CES categories of aesthetics, sense of place, and social cohesion was also revealed. CES categories tended to be positively linked with each other. The valuation of CES was diverse depending on gender, income, educational background, and visiting frequency. Respondents prioritized government and community roles over the role of individuals and international and national non-government organizations in managing CES. Collaboration between individual and organizations was deemed a high priority. Our results highlight that a better understanding of CES and how different people perceive their benefits can be used to foster public participation and increase support for green space management initiatives.
\end{abstract}

Key Words: cultural ecosystem services; Dhaka city; green space management; sustainability; urban green space;

\section{INTRODUCTION}

The world has been experiencing a critical period of urbanization in its history, with continued urban growth contributing to human population densification and a significant loss of green spaces (Lin et al. 2015, Munyati and Drummond 2020). Urban green spaces are the main natural elements in cities and play an essential role in sustainable urban growth through the provision of ecological, economic, and social benefits (Xu et al. 2020). Previous studies have argued that urban green spaces, including parks, gardens, children's playgrounds, green roofs, residential green spaces, streetside greeneries, green areas, and other open natural areas, have intangible cultural properties (Ko and Son 2018). Urban green spaces generate a wide range of benefits, called ecosystem services (ES), such as biodiversity, air quality improvement, rainwater regulation, and emissions minimization (Bolund and Hunhammer 1999, Bowler et al. 2010, Chan et al. 2012a, Faehnle 2014, Riechers et al. 2018, 2019). Quality of life, including health and well-being in cities, largely depends on the ES that urban green spaces provide. For ensuring the proper delivery of ES, multifunctional, accessible, and heterogeneous green spaces throughout urban areas are essential (GomezBaggethun et al. 2013). Successful protection of green spaces in accessible urban locations requires the development of policy and management strategies with national support and the involvement of local people and managers (Andersson et al. 2015).

In Bangladesh, more than $35 \%$ of the population lives in urban areas (World Bank 2016). The urban population in this country tripled from 1990 to 2019 (https://data.worldbank.org/indicator/ SP.URB.GROW? locations=BD, cited in Dewan et al. 2021).
Rapid urbanization is challenging for developing countries like Bangladesh (Rana 2011) because it causes pressure on social, environmental, and economic well-being (Zinia and McShane 2018) and a sharp reduction in natural greenness (Rai et al. 2017, Dewan et al. 2021). For instance, urban houses in this country are of poor quality and mostly built on illegally occupied land, resulting in a lack of the infrastructure necessary to protect residents from disasters and other adversities (Ahammad 2011). This is especially true in Dhaka, Bangladesh's capital city, which is burdened with an annual population growth rate of $3.5 \%$ (BBS 2015). Dhaka is located at $23^{\circ} 42^{\prime} \mathrm{N}$ and $90^{\circ} 22^{\prime} \mathrm{E}$ on the eastern banks of the Buriganga river, with a highly dense population of 30,551 people $/ \mathrm{km}^{2}$ (BBS 2015). Rapidly growing, disorganized urbanization in Dhaka city has caused congestion and contributes to unhealthy lifestyles (Rahman and Zhang 2018). Furthermore, the rise of Dhaka city comes with a loss of green areas (Chowdhury and Faruqui 1989, Byomkesh et al. 2012). Urban management strategies of Bangladesh mainly focus on disaster and climate change management because the country is frequently affected by disasters (Dewan et al. 2021). However, inhabitants' needs for green space and its management are often ignored (Rahman and Zhang 2018).

ES are considered a helpful doorway for managing nature, such as green space, in cities (Andersson et al. 2015). The Millennium Ecosystem Assessment (MEA) explained ES as the benefits people receive from the ecosystem (MEA 2005). These include provisioning services (e.g., food, water), regulating services (e.g., climate regulation), cultural services (e.g., recreational, aesthetic), and supporting services (e.g., soil formation). The MEA defines CES as "nonmaterial" benefits that people derive from ecosystems 
through "spiritual enrichment, cognitive development, reflection, recreation, and aesthetic experiences" (MEA 2005: 40). In this study, we use the definition of CES derived from Russell et al. (2013: 475) as “ecosystems' contributions to human well-being mediated through non-material processes (e.g., the mind or culture)." This definition expressly includes direct experiences of nature, and the benefits are understood through human cognitive perception. Human-nature interactions are made sustainable through CES because CES in some way accommodates ecological conservation outcomes, human preferences, and values (Chan and Satterfield 2015, Arias-Arévalo et al. 2017). Research on CES is considered to move the process of sustainable development forward by identifying and valuing CES (Chakraborty and Gasparatos 2019, Chakraborty et al. 2020) experienced in cities, understanding the way urban green spaces motivate stewardship and public participation, and assessing how CES can be included in policies and development strategies (Chan et al. 2012a, Andersson et al. 2015).

Solutions to ecological problems are generally implemented by decision makers in a "top-down" manner. Therefore, a grassroots perspective from Dhaka residents is needed because previous studies show that experts' opinions on CES differs from laypeople's opinions (Nahuelhual et al. 2016, Riechers et al. 2017, Russel and Turnpenny 2020). Taking these views into account, we aimed to highlight residents' perceptions on the importance of CES and their views on how best to manage such services. Analysis of resident perceptions in this way is minimal in the literature, especially in the Global South. Thus, we explored three research questions: (1) what importance do urban residents place on aspects of the green space CES, (2) what characteristics of residents are associated with their perceptions about the CES, and (3) what are residents' perceptions about how CES can be most effectively managed?

Current trends suggest that green spaces in cities like Dhaka will continue to meet significant pressure in the face of conflicting demands for land. Understanding how residents perceive the importance of CES and how they think CES should be managed holds great promise for informing sustainable urban development that preserves and expands green spaces.

\section{LITERATURE REVIEW}

In Dhaka city, urban green spaces include rooftop gardens, parks, gardens, community gardens, and green walls (Zinnia and McShane 2018). Urban green spaces have special significance because they provide cultural services to urban residents (Riechers et al. 2019). We reviewed the literature on CES provided by different urban green spaces from different parts of the world and found that different types of green spaces provide different CES, and some of the CES are space-specific (Table 1). For instance, urban parks provide CES that include recreation and natural awareness, gardens that offer recreation and learning, and historical places that support cultural heritage.

CES is still poorly explored, particularly in urban areas, but is increasingly required for humans' welfare (Radford and James 2013). Previous CES research employed the term "cultural services" either without differentiating between different types of green space and respective services offered or focusing on single examples, such as "recreation and tourism." There is limited understanding of the importance of a whole range of urban green
CES from the urbanites' perspective (see exceptions by Riechers et al. 2018, Shi et al. 2020), especially in the Global South. Urbanites from varied social backgrounds perceive nature based on their cultural values and beliefs (Faehnle et al. 2014). Respondents' social background and green space visiting frequency are major concerns when trying to understand the valuation of CES (Riechers et al. 2019). Urbanites are very connected to CES provided by ecosystems. Urbanites attribute different cultural values and figurative meaning to nature. Park visitors may, for instance, use the term "diversity" without scientific knowledge of biodiversity concerning the number of species, richness, etc. (Voigt and Wurster 2015). Instead, the term is used to articulate that they value the beauty of urban green space and the importance of protecting it from deterioration. Previous research has also identified a connection between CES, public engagement, and sustainability (Colding and Barthel 2013, Andersson et al. 2014, Gould et al. 2014, Chakraborty et al. 2020). Individuals and communities prefer to support management actions when those actions improve CES (Dendoncker et al. 2013, Andersson et al. 2015). Hansen and Pauleit (2014) suggested combining green space and ecosystem services approaches with development strategies that capture complex human-nature relationships in urban regions and that support policy objectives such as social cohesion.

Further, the study by Pauleit et al. (2019) suggested contextsensitive development of urban green space that reflects the diversity of residents' demands and practices concerning urban green spaces. Urban management often lacks the inclusion of citizens' perceptions or participation in management concepts, planning, and implementation (Ahmed et al. 2019). Previous research on managing urban green space has often considered ecological and economic benefits (e.g., Zinia and McShane 2018, Sun et al. 2019). However, the incorporation of social and cultural services from urban green space into the decision-making process lags far behind (Shi et al. 2020). Therefore, our study's contribution is to address the gap concerning cultural services offered by green spaces and to do so by analyzing residents' perceptions.

To date, CES research has centered primarily on market services such as tourism and entertainment, and such assessments have primarily used monetary estimation (Cheng et al. 2019). However, in recent years, CES researchers have started using non-monetary methods, owing to the difficulty of monetizing intangible benefits arising from highly diverse green spaces in the presence of complex social factors (Christie et al. 2012, Gómez-Baggethun et al. 2013). Non-monetary methods include, first, "revealed preference" (e.g., researcher observations, social-media-based analysis, document review) and second, "stated preference" (e.g., interviews with and/or surveys of local people; Cheng et al. 2019). The stated preference method allows residents to clarify their genuine perceptions and expectations about the CES (such as aesthetics, sense of place, education, and spiritual and religious aspects), and to suggest the values neglected by the monetary and revealed preference methods (Christie et al. 2012, Larson et al. 2019, Shi et al. 2020). The efficacy of stated preference approaches for the collection of CES data is further confirmed by a comparative analysis by Willcock et al. (2017). Thus, the stated preference method has generated increasing interest among CES researchers, and the "questionnaire method" (one type of stated 
Table 1. Cultural Ecosystem Services at country scale and its linkage to urban green spaces.

\begin{tabular}{|c|c|c|c|}
\hline Cultural Ecosystem Services (CES) & $\begin{array}{l}\text { Linkages to Green } \\
\text { Space }\end{array}$ & Urban area & References \\
\hline Recreational value & $\begin{array}{l}\text {-Green park } \\
\text {-Sports park } \\
\text {-Urban vegetation }\end{array}$ & $\begin{array}{l}\text { Gwacheon, Republic of Korea, } \\
\text { Ghana }\end{array}$ & $\begin{array}{l}\text { Ko and Son (2018) } \\
\text { Dumenu (2013) }\end{array}$ \\
\hline Cultural heritage & $\begin{array}{l}\text {-Museum } \\
\text {-Historical place }\end{array}$ & Gwacheon, Republic of Korea & Ko and Son (2018) \\
\hline \multirow[t]{2}{*}{ Aesthetic value } & $\begin{array}{l}\text {-Mountain } \\
\text {-Green parks } \\
\text {-Urban forest }\end{array}$ & $\begin{array}{l}\text { Gwacheon, Republic of Korea, } \\
\text { South Africa } \\
\text { USA }\end{array}$ & $\begin{array}{l}\text { Ko and Son (2018) } \\
\text { Shackleton et al. (2018) }\end{array}$ \\
\hline & & $\begin{array}{l}\text { Berlin, Germany } \\
\text { Kuala Lumpur, Malaysia }\end{array}$ & $\begin{array}{l}\text { Sherrouse and Semmens (2014) } \\
\text { Kazmierczak and Carter (2010), } \\
\text { Francis and Lorimer (2011) } \\
\text { Rahman et al. (2015) }\end{array}$ \\
\hline \multirow[t]{2}{*}{ Inspiration } & $\begin{array}{l}\text {-Green park } \\
\text {-Urban forest }\end{array}$ & Berlin, Germany & Riechers et al. (2018) \\
\hline & $\begin{array}{l}\text {-Lake } \\
\text {-Cultural place }\end{array}$ & Xuzhou, China & Dai et al. (2019) \\
\hline Educational value & $\begin{array}{l}\text {-Museum } \\
\text {-Historical place } \\
\text {-Botanical park }\end{array}$ & $\begin{array}{l}\text { Gwacheon, Republic of Korea } \\
\text { Xuzhou, China }\end{array}$ & Ko and Son (2018) \\
\hline Social relations & $\begin{array}{l}\text {-Parks } \\
\text {-Garden }\end{array}$ & Berlin, Germany & $\begin{array}{l}\text { Dal et al. (2019) } \\
\text { Riechers et al. (2018) }\end{array}$ \\
\hline Sense of place & $\begin{array}{l}\text {-Urban park } \\
\text {-Lake } \\
\text {-Garden }\end{array}$ & New York, USA & Johnson et al. (2019) \\
\hline \multirow[t]{2}{*}{ Natural awareness } & $\begin{array}{l}\text {-Urban park } \\
\text {-Garden } \\
\text {-Mountain }\end{array}$ & Berlin, Germany & Riechers et al. (2018) \\
\hline & -Rooftop garden & Gwacheon, Republic of Korea & Ko and Son (2018) \\
\hline Spiritual value & -Mountain & $\begin{array}{l}\text { Gwacheon, Republic of Korea } \\
\text { Kenya }\end{array}$ & Ko and Son (2018) \\
\hline \multirow[t]{2}{*}{ Mental satisfaction/ Relieve stress } & $\begin{array}{l}\text {-Green park } \\
\text {-Garden }\end{array}$ & South Africa & $\begin{array}{l}\text { Adekunle et al. (2013) } \\
\text { Shackleton et al. (2018) }\end{array}$ \\
\hline & $\begin{array}{l}\text {-Pond, lake } \\
\text {-Urban forest }\end{array}$ & USA & Sherrouse and Semmens (2014) \\
\hline
\end{tabular}

preference method) is being used effectively to value CES in a non-monetary way (Cheng et al. 2019). Furthermore, studies have started to analyze variables that influence CES preferences and have suggested the need to understand the influence of individual variables (e.g., respondents' gender) on perceptions of CES (Shi et al. 2020).

The evidence is clear that CES is vital to residents' quality of life. However, the subject is often neglected by policy makers, and academic work that seeks to inform policy making is lacking. Countries usually have fewer policies to maintain CES, which results in difficulties in accounting for CES management (Pleasant et al. 2014). A review by Gould et al. (2019) revealed that only $27 \%$ of 232 published papers discuss CES' links to decision making in general terms, $28 \%$ discuss specific influences on decision making, and the remainder mention the decisionmaking connection briefly or not at all. We assessed residents' perceptions of their own role and their perceptions of decisionmakers' and managers' roles in managing (Zinia and McShane 2018) CES from specific urban green spaces.

Perception of the benefits of CES depends upon individual context and social factors (Braat and de Groot 2012, Riechers et al. 2018). However, in-depth studies on assessing residents' perception of CES within a management context are minimal. Thus, to fill this research gap, the present study aims to understand how the importance of CES is perceived by Dhaka residents, how this perception varies depending on residents' background and visiting frequency, and the role of individuals and institutions in managing CES.

\section{MATERIALS AND METHODS}

\section{Study area}

The urban development in Dhaka megacity has not been parallel with the fast growth of the city (BBS 2015, Rahman and Zhang 2018). Seventy-eight percent of this city's green spaces were lost between 1975 and 2017 (Mundi 2018). According to Dhaka Structure Plan (2015), there are 41-46 parks and gardens in Dhaka city. Although Rajdhani Unnayan Kartipakkh (RAJUK), the authority responsible for developing Dhaka, planned for green space to make up $20 \%$ of the city, it has only $8 \%$ (Byomkesh et al. 2012). As depicted in Figure 1, Dhaka city is divided into two city corporations: Dhaka North City Corporation (DNCC) and Dhaka South City Corporation (DSCC). DSCC is divided into 10 zones; our study area lies in the zone-1 area. DSCC governs 57 southern wards of Dhaka city. The total area of DSCC is $43.961 \mathrm{~km}^{2}$, and zone- 1 covers $11.504 \mathrm{~km}^{2}$. This zone covers ward 
Fig. 1. Location of the study area.

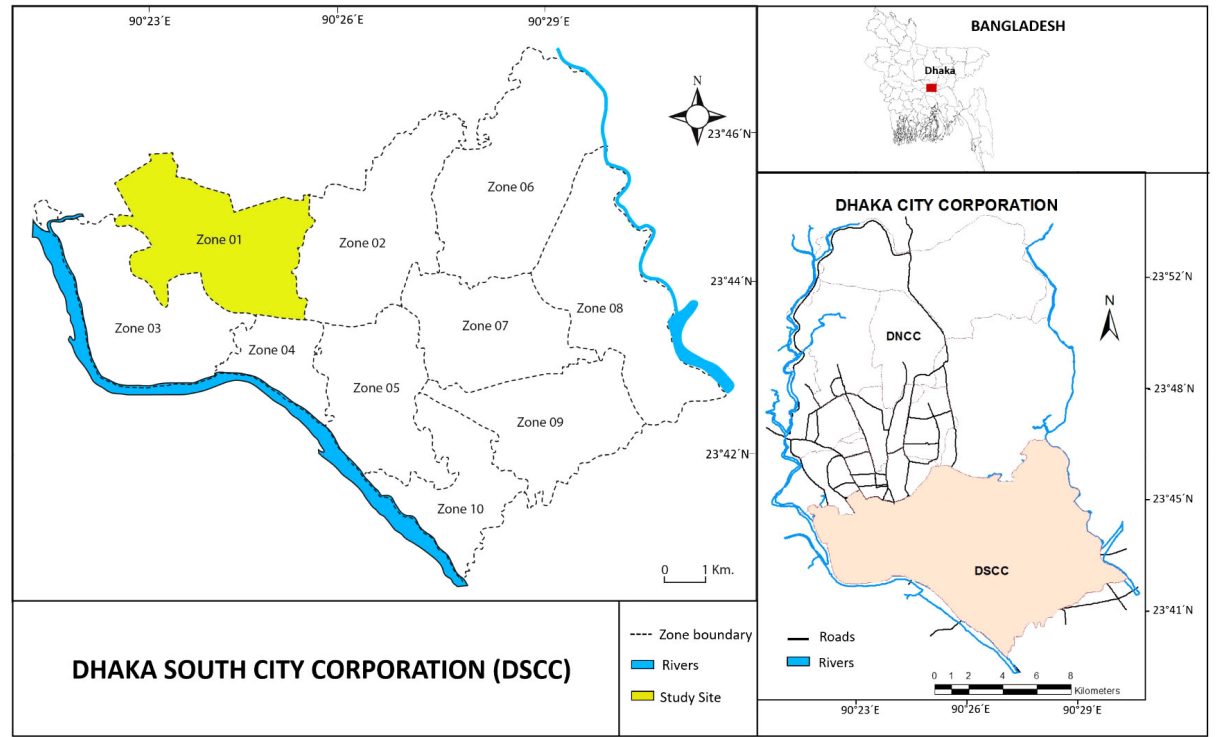

numbers 15 to 21 . There are 28 parks and 10 playgrounds in DSCC (DSCC 2020). The local government mainly takes the responsibility to manage the green spaces (e.g., parks, fields). However, previously it was reported that urban areas, including Dhaka, lack logistics and proper management strategies to manage green spaces efficiently (Heynen et al. 2006, Rahman and Zhang, 2018).

\section{Research design and data analysis}

Selection of the study site

We selected the zone-1 area based on field-level observations, personal experiences, expert judgments, and literature review. The socio-demographic condition (population, education, gender, income level) were similar across the wards in zone-1 (BBS 2013, DSCC 2020). We considered the presence of a variety of green spaces in this area, including lakes, parks, rooftop greeneries, and access to households for surveys during the selection process. Some zones (e.g., zone-4, DSCC) in Dhaka city have no green patches at all (Rahman and Zhang 2018), so those zones were not considered for this study. Residents of zone-1 provide a crosssectional overview of the residents who live in a privileged area of Dhaka city because they have access to green spaces such as Ramna Park, Dhanmondi Lake, green roofs, and householdassociated greeneries (Fig. 2). We needed to select a zone where green spaces are available, and, thus, user residents could perceive the role of those spaces and provide valuable information on CES provisioning and management.

\section{Questionnaire development and survey implementation}

To assess residents' perception of the importance of CES and suitable approaches for managing green space, we used a questionnaire-based stated preference method. This method supports analyzing social perceptions of CES in a consultative way and understands respondents' prioritization of services (Castro et al. 2011, Ciftcioglu 2017).
The preparation work for questionnaire development and survey included (1) an extensive review of the relevant literature concerning how CES is conceptualized CES, (2) separate focus groups with, respectively, experts and non-specialists to improve the language and structure of the questionnaire, and (3) a pilot of the questionnaire survey with the residents from the study area $(n=39)$.

Fig. 2. Green spaces in the study site. (a) green park (b) streetside greenery (c) rooftop garden (d) green landscape
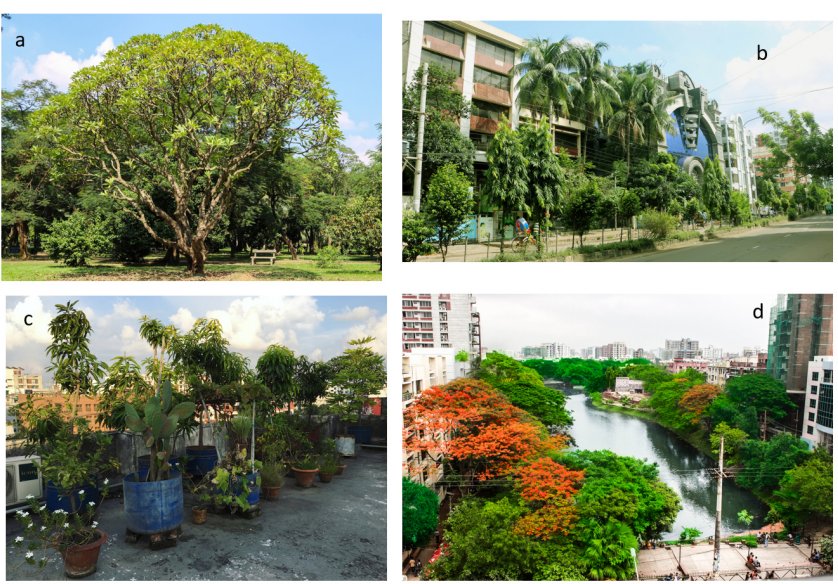

The final questionnaire focused on four points: first, respondents' gender, income, educational background, and green space visiting frequency; second, the perceived importance of CES (Appendix 1); third, the importance of green space in providing CES; and fourth, the importance of CES management (and green spacespecific management) by individuals and organizations. 
The CES categories were mainly adopted from the MEA (2005) to the context of Dhaka inhabitants. We substituted the CES category "traditional knowledge systems" with "natural awareness" and "cultural diversity" with "mental satisfaction" based on literature (Riechers et al. 2018) and preparatory questionnaire work. Previous studies have often substituted MEA CES categories. The categories are the bases of the MEA, and researchers develop other categories that incorporate CES concepts based on the needs of their specific study (e.g., Ko and Son 2018, Riecher et al. 2018, Shi et al. 2020). All the CES categories used in this study fit within the MEA concept of CES. Managerial entities of green space include individual, community, government, non-government organizations (NGO), and international non-government organizations (INGO). Further, based on Zinia and McShane's (2018) recommendations on ES management in Dhaka city, we focused on respondents' prioritization of the role of CES management by individual or collective effort (public collaboration with government/NGO/ INGO). Five-point Likert scales (from 1: not important to 5: very important) were used to collect data on the perceived importance of CES and CES management.

Data were collected between October 2018 and April 2019 using face-to-face questionnaire surveys of 405 households. Yamane's (1967) simple random sampling formula was used to determine the sample size with $\pm 5 \%$ precision assuming a $95 \%$ confidence level. The sampling frame included residents (older than 18) of zone-1 in DSCC. Surveys were conducted on various days of the week between 10:00 a.m. and 9:00 p.m. In our sample, 52.8\% (n $=214)$ of the respondents were male, and the rest $47.2 \%(n=191)$ were female. Most respondents held bachelor degrees $(43.5 \%, n$ $=176)$. Regarding income, $44.7 \%(\mathrm{n}=181)$ of the respondents' monthly income ranged from 25,000 to 75,000 Bangladeshi Taka $(\mathrm{BDT} ; 84.95 \mathrm{BDT}=\mathrm{US} \$ 1)$. Among the respondents, $47.7 \%(\mathrm{n}=$ 193) reported visiting green space weekly (Appendix 2).

\section{Data analysis}

Data were analyzed using the Statistical Package for Social Sciences (SPSS) version 26. The mean values of perceived importance of CES, green space for providing CES, the role of stakeholders, and importance of the individual and collective effort were calculated. We assessed relations between the perceived importance of $10 \mathrm{CES}$ categories using bivariate correlations (Pearson's $r$ coefficient; see similar methods in Riechers et al. 2018). An independent sample t-test was applied to understand the influence of gender on CES perception, and a paired sample t-test was applied to investigate the difference between the respondents' opinions (Shi et al. 2020) on CES management through individual and collective effort. One-way analysis of variance (ANOVA; see similar methods in Shi et al. 2020) followed by posthoc Tukey's tests were used to analyze the influence of respondents' income, educational background, and visiting frequency on the perceptions of CES.

\section{RESULTS}

\section{Perceived importance of green space based CES}

The overall assessment shows that the CES category recreation was perceived as most important, with a mean value of 4.03 . The second rank was reached by the importance of aesthetics (3.91), followed by a sense of place (3.79). The least important CES was cultural heritage (2.45; Fig. 3). The mean importance across 10 CES categories was 3.33. Among green spaces, rooftop gardens were considered most important in providing CES (Fig. 4), with a mean importance value of 4.22 , followed by green parks (4.06), and gardens (3.89).

Fig. 3. Perceived importance of cultural ecosystem services provided by urban green spaces. Criteria of assessment for mean index: $1=$ Not important, $2=$ Slightly important, $3=$ Moderately important, 4 = Important, $5=$ Very important. Error bars represent standard deviation.

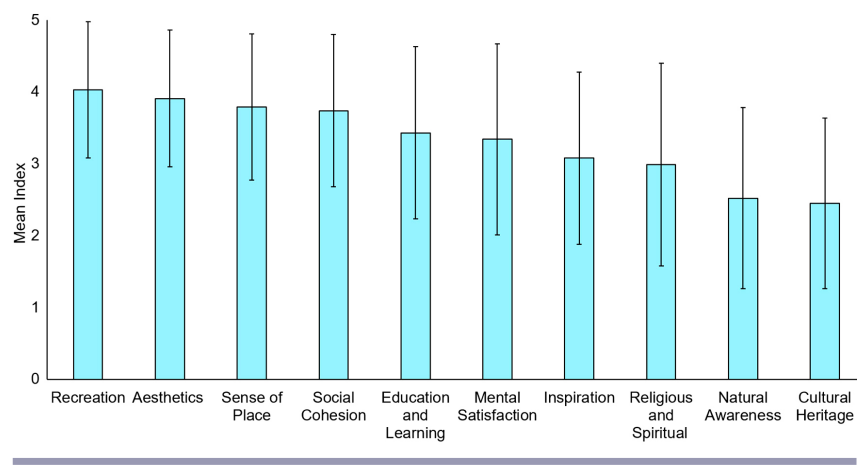

Fig. 4. Importance of green spaces for providing CES. Criteria of Assessment for mean index: $1=$ Not important, $2=$ Slightly important, $3=$ Moderately important, $4=$ Important, $5=$ Very important. Error bars represent Standard Deviation.

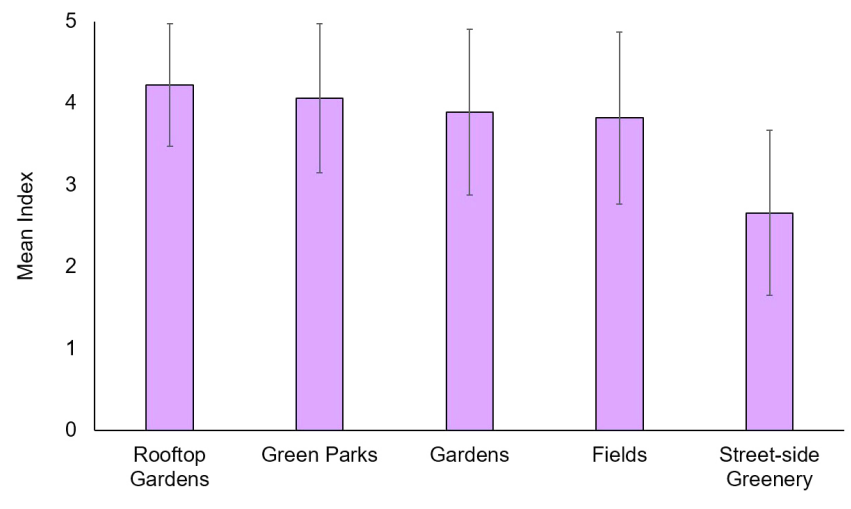

Bivariate correlations between the perceived importance of categories of CES revealed several sets of services, including two prominent ones (Fig. 5). The first and most prominent set includes relationships between natural awareness, religious and spiritual, and cultural heritage, with each relationship achieving a Pearsons $\mathrm{r}$ greater than 0.60 . Mental satisfaction, sense of place, and aesthetics form the second set of related categories (with Pearsons $\mathrm{r}$ values ranging from 0.30 to 0.60 ). Other sets with $\mathrm{r}$ values above 0.30 include education and learning and social cohesion or recreation, and inspiration and cultural heritage. Some other weakly bound sets (Pearsons $r<0.30$ ), including inspiration, religious and spiritual, and education and learning, were also revealed. Individual CES categories tended to correlate positively with each other, but some correlations between categories were negative (e.g., natural awareness and recreation). 
Fig. 5. Bivariate correlations between stated importance of cultural ecosystem services across participants, $p<0.01$ (2-sided). Strength of the arrows indicate the strength of Pearson's $r$ coefficients.

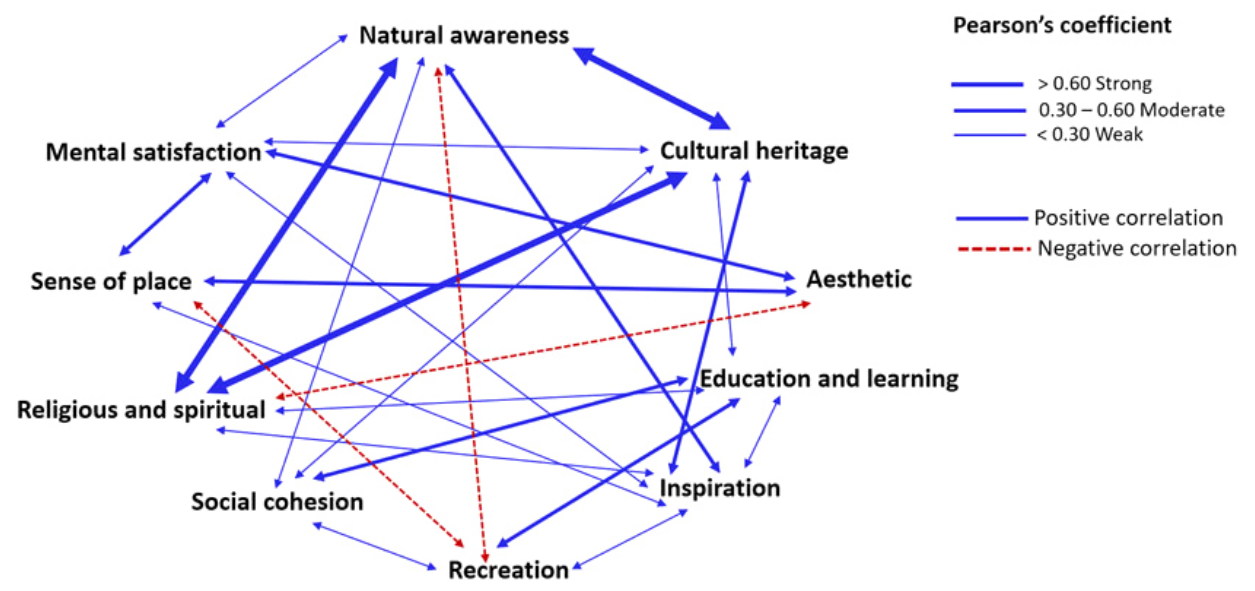

\section{Respondents' characteristics and CES valuation}

The four important variables that elucidate the perceived importance of CES categories were gender, income, education, and respondents' visiting frequency to green spaces. Results from an independent samples t-test revealed that the importance of the CES categories recreation and education and learning was perceived differently by male and female respondents (Table 2). Compared with men, women more highly rated the CES categories recreation (mean rate 4.21) and education and learning (mean rate 3.71). The results from one-way ANOVA with post hoc follow-up showed that respondents from the highest-income group (more than 150,000 BDT) placed more importance on cultural heritage than respondents from lower income groups (Table 2). Respondents' educational background significantly influenced their perception of the importance of the CES category recreation. Respondents who had never been to school rated the recreation category more highly (mean 4.36) than did respondents with other amounts of schooling.

In comparison to the above three variables (gender, income, and education), visiting frequency was found to significantly distinguish $(p<0.01)$ respondents' ratings of several CES categories: mental satisfaction, sense of place, recreation, education and learning, and social cohesion (Table 2). Daily visitors perceived recreation and social cohesion as the two most important CES categories (mean ratings of 4.57 and 4.37, respectively). On the other hand, yearly visitors rated mental satisfaction (mean 4.42) significantly higher than did respondents who visited more frequently.

\section{Perception of CES management}

Respondents from the study site prioritized the government's role in managing CES, with a mean score of 4.29 (Table 3), over the individual's, community's, NGO's, and INGO's role. However, the community role attracted the second-highest average rating (4.01; Table 3). Furthermore, $46.3 \%$ of the respondents indicated that the individual has an important role to manage CES. Results from paired-sample t-tests showed that respondents considered the collective role (public collaboration with government/ $\mathrm{NGO}$ /
INGO) significantly more important than the individual role in CES management for all types of green spaces except streetside greenery (Fig. 6). Green parks and rooftop gardens were perceived as the two most important green spaces to be managed collectively.

Fig. 6. Individual and collaborative effort for managing cultural ecosystem services. Criteria of assessment for mean index: $1=$ Not important, 2 = Slightly important, $3=$ Moderately important, 4 = Important, 5 = Very important. Error bars represent standard deviation. * shows significant difference at $<$ 0.001 based on paired sample t-test.

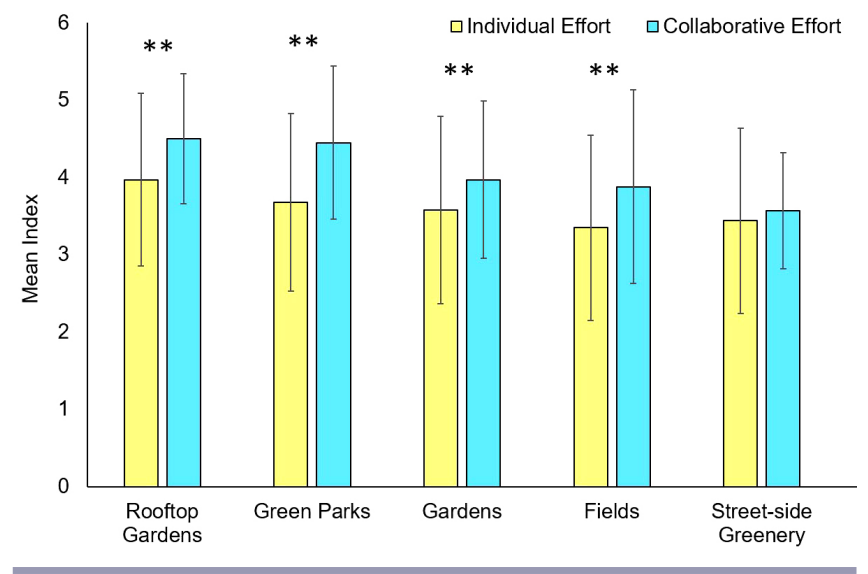

\section{DISCUSSION}

Importance of specific CES provisioning and places

Our findings indicated that recreational services were perceived as the most important CES category, and aesthetics were the second most important (Fig. 3) (results similar to Jim and Chen 2006, Riechers et al. 2018). In contrast with other studies (i.e., Ponizy et al. 2017), our results showed the high stated importance of CES related to sense of place and social cohesion. Research by Bertram and Rehdanz (2015) conducted in four European 
Table 2. Importance of cultural ecosystem services depending on the respondents' gender, income level, educational background, and visiting frequency to green spaces. Criteria of assessment: $1=$ Not important, $2=$ Slightly important, $3=$ Moderately important, $4=$ Important, 5 = Very important. a, b, and c are representing subgroups based on one way ANOVA followed by the least significant difference test (post-hoc Tukey's test). BDT = Bangladeshi Taka.

\begin{tabular}{|c|c|c|c|c|c|c|c|c|c|c|c|}
\hline \multirow{2}{*}{\multicolumn{2}{|c|}{ Residents characteristics }} & \multicolumn{10}{|c|}{ Cultural Ecosystem Services } \\
\hline & & $\begin{array}{c}\text { Mental } \\
\text { Satisfaction }\end{array}$ & $\begin{array}{l}\text { Sense } \\
\text { of } \\
\text { Place }\end{array}$ & Aesthetics & Recreation & $\begin{array}{c}\text { Education } \\
\text { and } \\
\text { Learning }\end{array}$ & $\begin{array}{c}\text { Social } \\
\text { Cohesion }\end{array}$ & $\begin{array}{l}\text { Religious } \\
\text { and } \\
\text { spiritual }\end{array}$ & $\begin{array}{c}\text { Natural } \\
\text { Awareness }\end{array}$ & $\begin{array}{l}\text { Cultural } \\
\text { Heritage }\end{array}$ & Inspiration \\
\hline \multicolumn{12}{|l|}{ Gender } \\
\hline & Male & 3.44 & 3.87 & 3.93 & 3.87 & 3.18 & 3.68 & 2.95 & 2.49 & 2.40 & 3.06 \\
\hline & Female & 3.22 & 3.71 & 3.88 & 4.21 & 3.71 & 3.81 & 3.04 & 2.55 & 2.51 & 3.10 \\
\hline & $P$ value & 0.31 & 0.17 & 0.91 & 0.00 & 0.00 & 0.39 & 0.32 & 0.57 & 0.34 & 0.19 \\
\hline \multicolumn{12}{|l|}{ Income } \\
\hline & $<25000 \mathrm{BDT}$ & 3.11 & 3.66 & 3.85 & 3.92 & 3.43 & 3.80 & 2.90 & 2.34 & $2.3^{\mathrm{a}}$ & 3.10 \\
\hline & 25000-75000 BDT & 3.48 & 3.82 & 3.88 & 4.18 & 3.50 & 3.81 & 3.01 & 2.47 & $2.36^{\mathrm{b}}$ & 3.11 \\
\hline & 75000-150000 BDT & 3.30 & 3.85 & 4.18 & 4.00 & 3.47 & 3.78 & 2.96 & 2.62 & $2.56^{\mathrm{b}}$ & 2.90 \\
\hline & $>150000 \mathrm{BDT}$ & 3.32 & 3.84 & 3.78 & 3.86 & 3.17 & 3.42 & 3.11 & 2.78 & $2.8^{\mathrm{c}}$ & 3.16 \\
\hline & $P$ value & 0.20 & 0.64 & 0.19 & 0.31 & 0.46 & 2.44 & 0.83 & 0.16 & 0.04 & 0.61 \\
\hline \multicolumn{12}{|c|}{ Education } \\
\hline & Never been to school & 3.39 & 3.67 & 3.91 & $4.36^{\mathrm{a}}$ & 3.72 & $4.15^{\mathrm{a}}$ & 3.07 & 2.78 & 2.57 & 2.73 \\
\hline & Primary School & 3.08 & 4.00 & 3.89 & $3.74^{\mathrm{b}}$ & 3.21 & $3.21^{\mathrm{b}}$ & 2.92 & 2.34 & 2.37 & 3.13 \\
\hline & Secondary School & 3.19 & 3.60 & 3.95 & $3.84^{\mathrm{ab}}$ & 3.37 & $3.65^{\mathrm{c}}$ & 2.75 & 2.28 & 2.34 & 3.06 \\
\hline & Graduate & 3.49 & 3.91 & 391 & $4.07^{\mathrm{ab}}$ & 3.47 & $3.74^{\mathrm{c}}$ & 3.09 & 2.65 & 2.58 & 3.10 \\
\hline & Post Graduate & 3.20 & 3.70 & 3.84 & $4.09^{\mathrm{ab}}$ & 3.22 & $3.84^{\mathrm{c}}$ & 3.02 & 2.31 & 2.15 & 3.36 \\
\hline & $P$ value & 0.25 & 0.10 & 0.98 & 0.03 & 0.34 & 0.02 & 0.50 & 0.11 & 0.17 & 0.13 \\
\hline \multicolumn{12}{|l|}{ Visiting } \\
\hline \multicolumn{12}{|l|}{ Frequency } \\
\hline & Daily & $2.90^{\mathrm{a}}$ & $3.46^{\mathrm{a}}$ & 3.67 & $4.57^{\mathrm{a}}$ & $4.00^{\mathrm{a}}$ & $4.37^{\mathrm{a}}$ & 2.78 & 2.33 & 2.21 & 2.95 \\
\hline & Weekly & $3.26^{\mathrm{a}}$ & $3.94^{b}$ & 3.93 & $3.99^{b}$ & $3.34^{\mathrm{b}}$ & $3.72^{\mathrm{b}}$ & 3.08 & 2.49 & 2.46 & 3.11 \\
\hline & Monthly & $3.25^{\mathrm{a}}$ & $3.74^{c}$ & 4.13 & $4.01^{\mathrm{b}}$ & $3.39^{\mathrm{b}}$ & $3.57^{\mathrm{ab}}$ & 2.96 & 2.63 & 2.51 & 3.05 \\
\hline & Yearly or less & $4.42^{b}$ & $3.85^{\mathrm{bc}}$ & 3.89 & $3.40^{\mathrm{c}}$ & $2.91^{\mathrm{b}}$ & $3.11^{\mathrm{c}}$ & 3.06 & 2.75 & 2.71 & 3.19 \\
\hline & $P$ value & 0.00 & 0.01 & 0.10 & 0.00 & 0.00 & 0.00 & 0.45 & 0.23 & 0.14 & 0.69 \\
\hline
\end{tabular}

cities (Berlin [Germany], Stockholm [Sweden], Rotterdam [The Netherlands], Salzburg [Austria]) demonstrated that the top three services provided by urban green space were related to physical and mental health and well-being. A similar result was found in studies by Chiesura (2004) and Zhang et al. (2013). They demonstrated that residents prefer physical and mental health benefits while visiting urban green spaces (i.e., parks). In line with these studies, our results suggest that recreation, aesthetics, and sense of place services are key reasons for residents to visit green space.

Among all the green spaces that exist in our study area, rooftop gardens, green parks, and gardens were perceived as the three most important to provide CES (Fig. 4). A study by Zinia and McShane (2018) found that rooftop gardens were the most used green adaptation strategy because of their economic feasibility and social acceptability. In our results, the rooftop garden attracted the highest importance in terms of providing ecosystem services. This may be because rooftop gardens can be accessed daily by an individual or community. However, most CES studies considered urban parks and gardens as important places to provide CES (Bertram and Rehdanz 2015, Riechers et al. 2018, 2019). An important aspect of CES is that some (e.g., inspiration, sense of place) are related to fishing, fruit picking, and vegetable gathering, and others are related to landscape view (Chan et al. 2012a, Plieninger et al. 2013). Such co-existence sometimes poses a challenge to conserve green spaces that provides multiple categories of CES. Furthermore, CES can also be valued differently by people from different social, demographic, and economic backgrounds (Plieninger et al. 2013, Riechers et al., 2018).

Our study revealed that many of the CES categories are correlated and associated with specific places (Appendix 4). A correlated set of indirectly-experienced CES categories (natural awareness, religious and spiritual, and cultural heritage) indicates the need for green spaces capable of providing those services specifically. However, in Dhaka city, multiple types of CES are being offered from a single kind of green space. For instance, urban parks are offering both direct (e.g., recreation) and indirect (e.g., aesthetics) kinds of CES. Urban green space offers outdoor meeting places, especially in populous areas. However, the use of urban green space for social interactions, including barbecues, parties, or sports, can impede and negatively affect CES provision for natural observation and recreation (Bertram and Rehdanz 2015). Because of the limited amount of green space, these differences may result in user conflict (Kabisch and Haase 2014). Thus, the utilization and management of CES in this area can become problematic. This problem stresses the need for proper urban green space management for sustainable urban development.

\section{Respondents' characteristics influencing CES valuation}

Our study showed the influence of the respondent's gender, income level, education, and visiting frequency on the perceived importance of CES provided by urban green spaces (Table 2). In contrast to Shi et al.'s (2020) finding for Gaoqu Township in 
Table 3. Importance of individual and organization in cultural ecosystem services management. Criteria of Assessment: $1=$ Not important, 2 = Slightly important, 3 = Moderately important, $4=$ Important, $5=$ Very important.

\begin{tabular}{|c|c|c|c|c|c|c|c|c|c|c|}
\hline & \multicolumn{2}{|c|}{ Individual } & \multicolumn{2}{|c|}{ Community } & \multicolumn{2}{|c|}{ Government } & \multicolumn{2}{|c|}{$\begin{array}{l}\text { Non-Governmental } \\
\text { Organization (NGO) }\end{array}$} & \multicolumn{2}{|c|}{$\begin{array}{c}\text { International Non- } \\
\text { Governmental Organization } \\
\text { (INGO) }\end{array}$} \\
\hline & Frequency & Percentage & Frequency & Percentage & Frequency & Percentage & Frequency & Percentage & Frequency & Percentage \\
\hline Not important & 19 & 4.7 & 9 & 2.2 & 15 & 3.7 & 11 & 2.7 & 19 & 5.2 \\
\hline $\begin{array}{l}\text { Slightly } \\
\text { important }\end{array}$ & 60 & 15.1 & 44 & 10.9 & 19 & 4.7 & 40 & 9.9 & 52 & 12.9 \\
\hline $\begin{array}{l}\text { Moderately } \\
\text { important }\end{array}$ & 54 & 13.1 & 48 & 11.9 & 57 & 14.1 & 76 & 18.8 & 92 & 22.8 \\
\hline Important & 84 & 20.7 & 137 & 33.9 & 55 & 13.6 & 150 & 37.1 & 109 & 27.0 \\
\hline Very important & 188 & 46.3 & 166 & 41.1 & 259 & 64.0 & 127 & 31.4 & 131 & 32.0 \\
\hline Mean Index & \multicolumn{2}{|c|}{3.89} & \multicolumn{2}{|c|}{4.01} & \multicolumn{2}{|c|}{4.29} & \multicolumn{2}{|c|}{3.85} & \multicolumn{2}{|c|}{3.68} \\
\hline SD & \multicolumn{2}{|c|}{1.26} & \multicolumn{2}{|c|}{1.08} & \multicolumn{2}{|c|}{1.10} & \multicolumn{2}{|c|}{1.06} & \multicolumn{2}{|c|}{1.19} \\
\hline
\end{tabular}

China, we found the effect of gender on specific categories of CES - recreation and education and learning - with women valuing these CES categories more highly than men. This finding is in line with Tyrväinen et al. (2007), Kaczynski et al. (2009), and Schipperijn et al. (2010), who found that women scored higher than men for similar CES-related activities. A study on Gothenburg on the Swedish west coast by Sang et al. (2016) revealed that, regardless of the type of green spaces, female respondents were more active than men respondents. However, while women in Dhaka city (one of the socially vulnerable groups) generate high demand for green space, their access to those spaces is limited by factors such as insecurity and traffic congestion (Rahman and Zhang 2018). Our results also showed that respondents' perceptions of CES categories varied by income level. Respondents with higher incomes valued green space for cultural heritage, whereas lower-income and less educated respondents placed more value on the recreation category. This may be because wealthy respondents are generally more knowledgeable and engaged in art, history, and culture. On the other hand, the lower-income inhabitants are rarely exposed to historical and cultural information because they remain busy earning money, living hand to mouth. Thus, they value the recreational aspect of green spaces because they can experience these directly.

A dichotomy was revealed in respondents' ratings by difference in visiting frequency. Respondents who visit green space daily prioritized recreational services and social cohesion. In contrast, respondents who visit those spaces yearly or less prioritized mental satisfaction (Table 2). Bertram and Rehdanz (2015) revealed the influence of visiting frequency on people's perception of the CES provided by green spaces. They found that respondents who visit green space more than once a month can perceive those places in detail; in contrast, the irregular visitor did not perceive CES accurately. Previous studies showed that park characteristics such as naturalness, spaciousness, sociability, cleanliness, and safety impact residents' visiting frequency to parks (Harrison et al. 2007, McCormack et al. 2010, Özgüner 2011, Zhang et al. 2013).

\section{Improving management of urban CES in Bangladesh}

Many respondents supported the collective role, mainly of the government, for the management of green spaces and associated CES. In contrast to our findings, Zinia and McShane's (2018) research found that Dhaka residents preferred to manage rooftop gardens individually. In our study, the rooftop gardens were found to be better managed collectively. Nowadays, Dhaka residents are mostly residing in apartments and sharing their roof with other apartment owners and tenants in the same building. Thus, collective maintenance is crucial. Moreover, supports and encouragement from the government may be needed for the proper management of rooftop gardens.

Our respondents placed high importance on collective efforts for managing CES provided by privately owned green spaces (e.g., rooftop garden) and open and public green (e.g., urban park) spaces. Rahman and Zhang's (2018) study also demonstrated the need for government and non-government collaboration to take the initiative on green space management to, for example, improve natural settings and increase security. CES may motivate residents to own, use, operate, or protect space for specific purposes, often related to amenities within the space (Chan et al. 2012b). CES affects the actions and activities of landowners in the management of private property (Plieninger et al. 2015). Literature suggests landlords have, over time, become more concerned with CES rather than solely with profit-maximization (Howley 2013, Hendee and Flint 2014).

Bangladesh has experienced tremendous urban growth since 1973 by converting green spaces into built-up areas (Hassan 2017). Thus, green space management strategies are urgently needed, and our results suggest a need to develop and manage green spaces that can sustainably provide multifunctional CES. Public management engagement is new for Dhaka, which is a crowded city with few private and public green spaces. Moreover, local people are culturally unfamiliar with the ecological benefits of green spaces. Thus, CES can be the starting point to engage local people in management and decision making. CES is a way to get people to manage green spaces collectively. Because CES is perceived and experienced directly, local people may feel empowered while managing CES with or without organizational (e.g., government, NGO, INGO) involvement. Changes in behavior through awareness-raising campaigns are also necessary for local people's proper utilization of green space for CES. Hence, the collaborative approach can be a suitable way to ensure public engagement to transition sustainable management plans to policies. 
In Dhaka, urban development strategies have mainly concentrated on densification and infrastructure development. Furthermore, urban management strategies have not involved inhabitants' participation in the conception, planning, and implementation phases (Ahmed et al. 2019). Inhabitants' perceptions of CES can inform urban management (Riechers et al. 2018). Large-scale research on the perceived importance of and preferences for urban green space and its management can help to understand the varied demands of CES that inhabitants from different social backgrounds can have. In our study, the findings on residents' preferences for CES in Dhaka city will improve urban managers' knowledge on the benefits of CES and ensure integration of inhabitants' demands and participation into urban green space management strategies.

For future studies, we suggest reduced item lists of CES because our study found strong correlations between CES categories. A previous study showed a detachment between more nature awareness-related CES categories (i.e., aesthetics, sense of place) and those focusing on social activities (i.e., social cohesion; Rall et al. 2017). Using the stated preference method through a questionnaire survey on a broader geographical scale to explore local peoples' perceptions of the importance and management of CES across regions can be one way to reflect citizens' perspective, preference and demand in management policies.

Although we can quantify the benefits from urban green spaces through various methods and approaches, the ecosystem service framework provides a powerful tool to quantitatively assess the importance and divergence of the ecosystem services among people. Our study adds to the limited available literature on the significance of urban green spaces from the Global South by emphasizing CES' importance and management from the inhabitants' perspective.

\section{CONCLUSION}

In Dhaka, the affordability and practicality of managing green spaces are challenged by environmental pollution, poverty, and unplanned, rapid development. For a climate-exposed city like Dhaka, management of green spaces is not only desirable but also essential for maintaining urban sustainability. CES is a strong entry point to engage the public in managing green spaces. Our study showed the influence of gender, income, educational background, and visiting frequency on CES valuation, with divergent perceptions emerging. Policy and planning related to urban green space management should consider such differences in CES demand from green spaces. Specifically, green spaces should create enough promises for diverse use aiming at recreation and aesthetics. Simultaneously, planners need to plan green spaces with recreational and social activities in areas that can be accessed daily. Prioritization of the rooftop garden among all spaces to provide CES suggests that planners may include favorable policy (e.g., tax exemption) for infrastructures with greenery on the rooftop. However, the high importance of green parks and gardens implies the need for efforts to manage these spaces. Respondents felt that the government could play the most crucial role in managing all these. Furthermore, the collaboration of individuals, community, government, NGO, and INGO was deemed a high priority. Consequently, CES provides the doorway to engage people with organization activities in managing the city to ensure a sustainable future. CES is a comfortable way for residents to relate green space to their lives, motivating them to be stewards of such spaces. A large-scale questionnaire survey similar to this study can be one tool that planners and policy makers can adapt and apply to assess CES' importance, and to engage the public in participatory urban management. Though research is emerging, more studies are needed in the Global South to understand people's perceptions of CES.

Responses to this article can be read online at: https://www.ecologyandsociety.org/issues/responses. $\mathrm{php} / 12656$

\section{Acknowledgments:}

We are grateful to Dr Debbie Bartlett, Principal Lecturer, Environmental Conservation Pharmaceutical, Chemical and Environmental Sciences, Faculty of Engineering and Science, University of Greenwich; and Dr Oliver Scanlan, Research Fellow and Dr Haseeb Md. Irfanullah, Visiting Research Fellow, Center for Sustainable Development (CSD), University of Liberal Arts Bangladesh (ULAB) for advice. We are thankful to the respondents and students of ULAB who helped us with data collection in Dhaka city and encouraged this publication. We are grateful to the respondents for participating in the questionnaire survey. We express our sincere thanks to the three anonymous reviewers for the comments, which greatly improved the quality of this manuscript.

\section{Data Availability:}

The data that support the findings of this study are available on request from the corresponding author, [R.S.].

\section{LITERATURE CITED}

Adekunle, M. F., B. M. Agbaje, and V. O. Kolade. 2013. Public perception of ecosystem service functions of peri-urban forest for sustainable management in Ogun State. African Journal of Environmental Science and Technology 7(6):410-416. http://dx. doi.org/10.5897/AJEST2012.1411

Ahammad, R. 2011. Constraints of pro-poor climate change adaptation in Chittagong city. Environment and Urbanization 23 (2):503-515. https://doi.org/10.1177/0956247811414633

Ahmed, S., M. Meenar, and A. Alam. 2019. Designing a bluegreen infrastructure (BGI) network: toward water-sensitive urban growth planning in Dhaka, Bangladesh. Land 8(9):138. https:// doi.org/10.3390/land8090138

Andersson, E., S. Barthel, S. Borgström, J. Colding, T. Elmqvist, C. Folke, and A. Gren. 2014. Reconnecting cities to the biosphere: stewardship of green infrastructure and urban ecosystem services. Ambio 43:445-453. https://doi.org/10.1007/s13280-014-0506-y

Andersson, E., M. Tengo, T. McPhearson, and P. Kremer. 2015. Cultural ecosystem services as a gateway for improving urban sustainability. Ecosystem Services 12:165-168. https://doi. org/10.1016/j.ecoser.2014.08.002 
Arias-Arévalo, P., B. Martín-López, and E. Gómez-Baggethun. 2017. Exploring intrinsic, instrumental, and relational values for sustainable management of social-ecological systems. Ecology and Society 22(4):43. https://doi.org/10.5751/ES-09812-220443

Bangladesh Bureau of Statistics (BBS). 2013. District statistics 2011. BBS, Dhaka, Bangladesh. [online] URL: http://203.112.218.65:8008/ WebTestApplication/userfiles/Image/District\%20Statistics/Dhaka. pdf

Bangladesh Bureau of Statistics (BBS). 2015. Bangladesh population and housing census 2011 community report Dhaka Zila. BBS, Dhaka, Bangladesh. [online] URL: http://bbs.dhaka. gov.bd/sites/default/files/files/bbs.dhaka.gov.bd/law policy/6ed6b42c_2015_11e7_8f57_286ed488c766/Socio-Economic and demographic Report 2012.pdf?fbclid=IwAR3B05X9 Ngg7W4zripR 8psoEHvaNjoSBxNQ3Dk4-5gY O7iLrnw_NU7I8

Bertram, C., and K. Rehdanz. 2015. Preferences for cultural urban ecosystem services: comparing attitudes, perception, and use. Ecosystem Services 12:187-199. https://doi.org/10.1016/j. ecoser.2014.12.011

Bolund, P., and S. Hunhammer. 1999. Ecosystem services in urban areas. Ecological Economics 29(2):293-301. https://doi. org/10.1016/S0921-8009(99)00013-0

Bowler, D. E., L. Buyung-Ali, T. M. Knight, and A. S. Pullin. 2010. Urban greening to cool towns and cities: a systematic review of the empirical evidence. Landscape and Urban Planning 97 (3):147-155. https://doi.org/10.1016/j.landurbplan.2010.05.006

Braat, L. C., and R. de Groot. 2012. The ecosystem services agenda: bridging the worlds of natural science and economics, conservation and development, and public and private policy. Ecosystem Services 1(1):4-15. https://doi.org/10.1016/j.ecoser.2012.07.011

Byomkesh, T., N. Nakagoshi, and A. M. Dewan. 2012. Urbanization and green space dynamics in Greater Dhaka, Bangladesh. Landscape and Ecological Engineering 8(1):45-58. https://doi.org/10.1007/s11355-010-0147-7

Castro, A. J., B. Martín-López, M. García-LLorente, P. A. Aguilera, E. López, and J. Cabello. 2011. Social preferences regarding the delivery of ecosystem services in a semiarid Mediterranean region. Journal of Arid Environments 75 (11):1201-1208. https://doi.org/10.1016/j.jaridenv.2011.05.013

Chakraborty, S., and A. Gasparatos. 2019. Community values and traditional knowledge for coastal ecosystem services management in the "satoumi" seascape of Himeshima island, Japan. Ecosystem Services 37:100940. https://doi.org/10.1016/j. ecoser.2019.100940

Chakraborty, S., S. K. Saha, and S. A. Selim. 2020. Recreational services in tourism dominated coastal ecosystems: bringing the non-economic values into focus. Journal of Outdoor Recreation and Tourism 30:100279. https://doi.org/10.1016/j.jort.2020.100279

Chan, K. M. A., A. D. Guerry, P. Balvanera, S. Klain, T. Satterfield, X. Basurto, A. Bostrom, R. Chuenpagdee, R. Gould, B. S. Halpern, N. Hannahs, J. Levine, B. Norton, M. Ruckelshaus, R. Russell, J. Tam, and U. Woodside. 2012. Where are cultural and social in ecosystem services? A framework for constructive engagement. Bio Science 62(8):744-756. https://doi.org/10.1525/ bio.2012.62.8.7

Chan, K. M. A., and T. Satterfield. 2015. Managing cultural ecosystem services for sustainability. Pages 343-351 in $\mathrm{M}$. Potschin, R. Haines-Young, R. Fish and R. K. Turner, editors. Routledge Handbook of Ecosystem Services. Routledge, Abingdon, Oxon.

Chan, K. M. A., T. Satterfield, and J. Goldstein. 2012. Rethinking ecosystem services to better address and navigate cultural values. Ecological Economics 74:8-18. https://doi.org/10.1016/j. ecolecon.2011.11.011

Cheng, X., S. V. Damme, L. Li, and P. Uyttenhove. 2019. Evaluation of cultural ecosystem services: a review of methods. Ecosystem Services 37:100925. https://doi.org/10.1016/j.ecoser.2019.100925

Chiesura, A. 2004. The role of urban parks for the sustainable city. Landscape and Urban Planning 68(1):129-138. https://doi. org/10.1016/j.landurbplan.2003.08.003.

Chowdhury, A., and S. Faruqui. 1989. Physical growth of Dhaka city. Pages 41-61 in S. U. Ahmed, editor. Dhaka: past, present and future Dhaka. The Asiatic Society of Bangladesh, Dhaka, Bangladesh.

Christie, M., L. Fazey, R. Cooper, T. Hyde, and J. O. Kenter. 2012. An evaluation of monetary and non-monetary techniques for assessing the importance of biodiversity and ecosystem services to people in countries with developing economies. Ecological Economics 83:67-78. https://doi.org/10.1016/j.ecolecon.2012.08.012

Ciftcioglu, C. G. 2017. Social preference-based valuation of the links between home gardens, ecosystem services, and human wellbeing in Lefke Region of North Cyprus. Ecosystem Services 25:227-236. https://doi.org/10.1016/j.ecoser.2017.05.002

Colding, J., and S. Barthel. 2013. The potential of 'urban green commons' in the resilience building of cities. Ecological Economics 86:156-166. https://doi.org/10.1016/j.ecolecon.2012.10.016

Dai, P., S. Zhang, H. Hou, Y. Yang, and R. Liu. 2019. Valuing sports services in urban parks: a new model based on social network data. Ecosystem Services 36: 100891. https://doi. org/10.1016/j.ecoser.2019.01.003

Dendoncker, N., H. Keune, S. Jacobs, and E. Gómez-Baggethun. 2013. Inclusive ecosystem services valuation. Pages 3-12 in S. Jacobs, N. Dendoncker, H. Keune, editors. Ecosystem services. Elsevier, Boston, USA. https://doi.org/10.1016/B978-0-12-4199$\underline{64-4.00001-9}$

Dewan, A., G. Kiselev, D. Botje, G. I. Mahmud, M. H. Bhuian, and Q. K. Hassan. 2021. Surface urban heat island intensity in five major cities of Bangladesh: patterns, drivers and trends. Sustainable Cities and Society 71:102926. https://doi.org/10.1016/ j.scs.2021.102926

Dhaka South City Corporation (DSCC). 2020. At one glance, Dhaka South. DSCC, Dhaka, Bangladesh. [online] URL: http:// www.dscc.gov.bd/site/page/c918f990-1f75-46cb-95ad-c08d10197af5/Dhaka Structure Plan. 2015. Dhaka Structure Plan Report 2016-2035. Rajdhani Unnayan Kartripakkha (RAJUK), 
Ministry of Housing and Public Works, Dhaka, Bangladesh [online] URL: https://www.rehab-bd.org/img/home_attach/Dhaka Structure Plan (2016-2035).pdf

Dumenu, W. K. 2013. What are we missing? Economic value of an urban forest in Ghana. Ecosystem Services 5:137-142. https:// doi.org/10.1016/j.ecoser.2013.07.001

Faehnle, M., P. Bäcklund, L. Tyrväinen, J. Niemelä, and V. YliPelkonen. 2014. How can residents' experiences inform planning of urban green infrastructure? Case Finland. Landscape and Urban Planning 130:171-183. https://doi.org/10.1016/j.

landurbplan.2014.07.012

Francis, R. A., and J. Lorimer. 2011. Urban reconciliation ecology: The potential of living roofs and walls. Journal of Environmental Management 92(6):1429-1437. https://doi. org/10.1016/j.jenvman.2011.01.012

Gómez-Baggethun, E. P., A. Gren, D. Barton, J. Langemeyer, T. McPhearson, P. O'Farrell, E. Andersson, Z. Hamstead, and P. Kremer. 2013. Urban ecosystem services. Pages 175-251 in T. Elmqvist, M. Fragkias, J. Goodness, B. Güneralp, P. J. Marcotullio, R. I. McDonald, S. Parnell, M. Schewenius, M. Sendstad, K. C. Seto, and C. Wilkinson, editors. Urbanization, biodiversity and ecosystem services: challenges and opportunities. Springer, Dordrecht, Netherlands. https://doi.org/10.1007/978-94-007-7088-1 11

Gould, R. K., N. M. Ardoin, U. Woodside, T. Satterfield, N. Hannahs, and G. C. Daily. 2014. The forest has a story: cultural ecosystem services in Kona, Hawai'i. Ecology and Society 19 (3):55. https://dx.doi.org/10.5751/ES-06893-190355

Gould, R. K., J. W. Morse, and A. B. Adam. 2019. Cultural ecosystem services and decision-making: how researchers describe the applications of their work. People and Nature 1:457-475. https://doi.org/10.1002/pan3.10044

Hansen, R., and S. Pauleit. 2014. From multifunctionality to multiple ecosystem services? A conceptual framework for multifunctionality in green infrastructure planning for urban areas. Ambio 43:516-529. https://doi.org/10.1007/s13280-014-0510-2

Harrison, R. A., I. Gemmell, and R. F. Heller. 2007. The population effect of crime and neighbourhood on physical activity: an analysis of 15461 adults. Journal of Epidemiology and Community Health 61:34-39. https://dx.doi.org/10.1136/ jech.2006.048389

Hassan, M. M. 2017. Monitoring land use/land cover change, urban growth dynamics and landscape pattern analysis in five fastest urbanized cities in Bangladesh. Remote Sensing Applications: Society and Environment 7:69-83. https://doi. org/10.1016/j.rsase.2017.07.001

Hendee, J. T., and C. G. Flint. 2014. Incorporating cultural ecosystem services into forest management strategies for private landowners: an Illinois case study. Forest Science 60 (6):1172-1179. http://dx.doi.org/10.5849/forsci.13-710

Heynen, N., H. A., Perkins, and P. Roy. 2006. The political ecology of uneven urban green space: the impact of political economy on race and ethnicity in producing environmental inequality in Milwaukee. Urban Affairs Review 42(1):3-25. https://doi. org/10.1177\%2F1078087406290729
Howley, P. 2013. Examining farm forest owners' forest management in Ireland: the role of economic, lifestyle and multifunctional ownership objectives. Journal of Environmental Management 123:105-112. https://doi.org/10.1016/j.jenvman.2013.03.013

Jim, C. Y., and W. Y. Chen. 2006. Perception and attitude of residents toward urban green spaces in Guangzhou (China). Environmental Management 38(3):338-349. https://doi.org/10.1007/ $\underline{\mathrm{s} 00267-005-0166-6}$

Johnson, M. L., L. K. Campbell, E. S. Svendsen, and H. L. McMillen. 2019. Mapping urban park cultural ecosystem services: A comparison of twitter and semi-structured interview methods. Sustainability 11(21):6137. https://doi.org/10.3390/ su11216137

Kabisch, N., and D. Haase. 2014. Green justice or just green? Provision of urban green spaces in Berlin, Germany. Landscape and Urban Planning 122:129-139. https://doi.org/10.1016/j. landurbplan.2013.11.016

Kaczynski, A. T., L. R. Potwarka, B. J. A. Smale, and M. E. Havitz. 2009. Association of parkland proximity with neighborhood and park-based physical activity: variations by gender and age. Leisure Sciences 31:174-91. https://doi. org/10.1080/01490400802686045

Kazmierczak, A., and G. Carter. 2010. Adaptation to climate change using green and blue infrastructure: A database of case studies. The University of Manchester, Manchester, England. [online] URL: https://orca.cardiff.ac.uk/64906/1/

Database Final no hyperlinks.pdf?fbclid=IwAR0WLNJRjhxKi2C VoyGPy5zX5DyXWsVz9xXO pAfHqh t1XbCV6X5W6sA

Ko, H., and Y. Son. 2018. Perceptions of cultural ecosystem services in urban green spaces: a case study in Gwacheon, Republic of Korea. Ecological Indicators 91:299-306. https://doi. org/10.1016/j.ecolind.2018.04.006

Larson, K. L., E. A. Corley, R. Andrade, S. J. Hall, A. M. York, S. Meerow, P. Coseo, D. L. Childers, and D. M. Hondula. 2019. Subjective evaluations of ecosystem services and disservices: an approach to creating and analyzing robust survey scales. Ecology and Society 24(2):7. https://doi.org/10.5751/ES-10888-240207

Lin, B., J. Meyers, and G. Barnett. 2015. Understanding the potential loss and inequities of green space distribution with urban densification. Urban Forestry \& Urban Greening 14 (4):952-958. https://doi.org/10.1016/j.ufug.2015.09.003

McCormack, G. R., M. Rock, A. M. Toohey, and D. Hignell. 2010. Characteristics of urban parks associated with park use and physical activity: a review of qualitative research. Health Place 16(4):712-726. https://doi.org/10.1016/j.healthplace.2010.03.003

Millennium Ecosystem Assessment (MEA). 2005. Ecosystems and human well-being: synthesis. Island Press, Washington, DC, USA. [online] URL: https://www.millenniumassessment.org/ documents/document.356.aspx.pdf

Mundi, I. 2018. Bangladesh Demographics Profile. [online] URL: https://www.indexmundi.com/bangladesh/demographics_profile. $\underline{\mathrm{html}}$ 
Munyati, C. and J. H. Drummond. 2020. Loss of urban green spaces in Mafikeng, South Africa. World Development Perspectives 19:100226. https://doi.org/10.1016/j.wdp.2020.100226

Nahuelhual, L., F. B. Ochoa, F. Rojas, G. I. Díaz, and A. Carmona. 2016. Mapping social values of ecosystem services: what is behind the map? Ecology and Society 21(3):24. https://dx. doi.org/10.5751/ES-08676-210324

Özgüner, H. 2011. Cultural differences in attitudes towards urban parks and green spaces. Landscape Research 36(5):599-620. https://doi.org/10.1080/01426397.2011.560474

Pauleit, S., B. Ambrose-Oji, E. Andersson, B. Anton, A. Buijs, D. Haase, B. Elands, R. Hansen, I. Kowarik, J. Kronenberg, T. Mattijssen, A. S. Olafsson, A. Rall, A. P. N. van der Jagt, and C. K. van den Bosch. 2019. Advancing urban green infrastructure in Europe: outcomes and reflections from the GREEN SURGE project. Urban Forestry \& Urban Greening 40:4-16. https://doi. org/10.1016/j.ufug.2018.10.006

Pleasant, M. M., S. A. Gray, C. Lepczyk, A. Fernandes, N. Hunter, and D. Ford. 2014. Managing cultural ecosystem services. Ecosystem Services 8:141-147. https://doi.org/10.1016/j.ecoser.2014.03.006

Plieninger., T., C. Bieling, N. Fagerholm, A. Byg, T. Hartel, P. Hurley, C. A. López-Santiago, N. Nagabhatla, E. Oteros-Rozas, C. M. Raymond, D. der Horst, and L. Huntsinger. 2015. The role of cultural ecosystem services in landscape management and planning. Current Opinion in Environmental Sustainability 14:28-33. https://doi.org/10.1016/j.cosust.2015.02.006

Plieninger, T., S. Dijks, E. Oteros-Rozas, and C. Bieling. 2013. Assessing, mapping, and quantifying cultural ecosystem services at community level. Land Use Policy 33:118-129. https://doi. org/10.1016/j.landusepol.2012.12.013

Ponizy, L., W. Majchrzak, and I. Zwierzchowska. 2017. Cultural ecosystem services of urban green spaces-supply and demand in the densely built-up areas. Poznan Old Town case study. Proceedings of World Multidisciplinary Earth Sciences Symposium 95(5):052009. https://doi.org/10.1088/1755-1315/95/5/052009

Radford, K. G., and P. James. 2013. Changes in the value of ecosystem services along a rural-urban gradient: a case study of Greater Manchester, UK. Landscape and Urban Planning 109 (1):117-127. https://doi.org/10.1016/j.landurbplan.2012.10.007 Rahman, S. R. A., H. Ahmad, S. Mohammad, and M. S. F. Rosley. (2015). Perception of green roof as a tool for urban regeneration in a commercial environment: the secret garden, Malaysia. Procedia-Social and Behavioral Sciences 170(27):128-136. https:// doi.org/10.1016/j.sbspro.2015.01.022

Rahman, K. M. A., and D. Zhang. 2018. Analyzing the level of accessibility of public urban green spaces to different socially vulnerable groups of people. Sustainability 10(11):3917. https:// doi.org/10.3390/su10113917

Rai, R., Y. Zhang, B. Paudel, S. Li, and N. R. Khanal. 2017. A synthesis of studies on land use and land cover dynamics during 1930-2015 in Bangladesh. Sustainability 9(10):1866. https://doi. org/10.3390/su9101866

Rall, E., C. Bieling, S. Zytynska, and D. Haase. 2017. Exploring city-wide patterns of cultural ecosystem service perceptions and use. Ecological Indicators 77:80-95. https://doi.org/10.1016/j. ecolind.2017.02.001

Rana, M. M. P. 2011. Urbanization and sustainability: challenges and strategies for sustainable urban development in Bangladesh. Environment Development and Sustainability 13:237-256. https://doi.org/10.1007/s10668-010-9258-4

Riechers, M., J. Barkmann, and T. Tscharntke. 2018. Diverging perceptions by social groups on cultural ecosystem services provided by urban green. Landscape and Urban Planning 175:161-168. https://doi.org/10.1016/j.landurbplan.2018.03.017

Riechers, M., E. M. Noack, and T. Tscharntke. 2017. Experts' versus laypersons' perception of urban cultural ecosystem services. Urban Ecosystem 20:715-727. https://doi.org/10.1007/ $\underline{\text { s11252-016-0616-3 }}$

Riechers, M., M. Strack, J. Barkmann, and T. Tscharntke. 2019. Cultural ecosystem services provided by urban green change along an urban-periurban gradient. Sustainability 11(3):645. https://doi.org/10.3390/su11030645

Russell, R., A. D. Guerry, P. Balvanera, R. K. Gould, X. Basurto, K. M. A. Chan, S. Klain, J. Levine, and J. Tam. 2013. Humans and nature: how knowing and experiencing nature affect wellbeing. Annual Review of Environment and Resources 38:473-502. https://doi.org/10.1146/annurev-environ-012312-110838

Russel, D. J., and J. Turnpenny. 2020. Embedding ecosystem services ideas into policy processes: an institutional analysis. Ecology and Society 25(1):9. https://doi.org/10.5751/ES-11342-250109

Sang, A. O., I. Knez, B. Gunnarsson, and M. Hedblom. 2016. The effects of naturalness, gender, and age on how urban green space is perceived and used. Urban Forestry \& Urban Greening 18:268-276. https://doi.org/10.1016/j.ufug.2016.06.008

Schipperijn, J., O. Ekholm, U. K. Stigsdotter, M. Toftager, P. Bentsen, F. Kamper-Jørgensen, and T. B. Randrup. 2010. Factors influencing the use of green space: results from a Danish national representative survey. Landscape and Urban Planning 95 (3):130-137. https://doi.org/10.1016/j.landurbplan.2009.12.010

Shackleton, C. M., A. Blair, P. De Lacy, H. Kaoma, N. Mugwagwa, M. T. Dalu, and W. Walton. 2018. How important is green infrastructure in small and medium-sized towns? Lessons from South Africa. Landscape and Urban Planning 180:273-281. https://doi.org/10.1016/j.landurbplan.2016.12.007 Sherrouse, B. C., and D. J. Semmens. 2014. Validating a method for transferring social values of ecosystem services between public lands in the Rocky Mountain region. Ecosystem Services 8:166-177. https:// doi.org/10.1016/j.ecoser.2014.03.008

Shi, Q., H. Chen, X. Liang, H. Zhang, and D. Liu. 2020. Cultural ecosystem services valuation and its multilevel drivers: a case study of Gaoqu Township in Shaanxi Province, China. Ecosystem Services 41:101052. https://doi.org/10.1016/j.ecoser.2019.101052

Sun, Y., S. Xie, and S. Q. Zhao. 2019. Valuing urban green spaces in mitigating climate change: a city-wide estimate of aboveground carbon stored in urban green spaces of China's Capital. Global Change Biology 25(5):1717-1732. https://doi.org/10.1111/ gcb. 14566 
Tyrväinen, L., K. Mäkinen, and J. Schipperijn. 2007. Tools for mapping social values of urban woodlands and other green areas. Landscape and Urban Planning 79(1):5-19. https://doi. org/10.1016/j.landurbplan.2006.03.003

Voigt, A., and D. Wurster. 2015. Does diversity matter? The experience of urban nature's diversity: case study and cultural concept. Ecosystem Services 12:200-208. https://doi.org/10.1016/ j.ecoser.2014.12.005

Willcock, S., B. J. Camp, and S. H. Peh. 2017. A comparison of cultural ecosystem service survey methods within South England. Ecosystem Services 26:445-450. https://doi.org/10.1016/j.

ecoser.2016.06.012

World Bank. (2016). Urban population (\% of total population). World Bank Group, Washington, D.C., USA. [online] URL: https://data.worldbank.org/indicator/SP.URB.TOTL.IN.ZS

Xu, F., Y. Wang, N. Xiang, J. Tian, and L. Chen. 2020. Uncovering the willingness-to-pay for urban green space conservation: a survey of the capital area in China. Resources, Conservation and Recycling 162:105053. https://doi.org/10.1016/j.resconrec.2020.105053

Yamane, T. 1967. Statistics: an introductory analysis. Harper and Row, New York, New York, USA.

Zhang, H., B. Chen, Z. Sun, and Z. Bao. 2013. Landscape perception and recreation needs in urban green space in Fuyang, Hangzhou, China. Urban Forestry and Urban Greening 12 (1):44-52. https://doi.org/10.1016/j.ufug.2012.11.001

Zinia, N. J., and P. McShane. 2018. Ecosystem services management: an evaluation of green adaptations for urban development in Dhaka, Bangladesh. Landscape and Urban Planning 173:23-32. https://doi.org/10.1016/j.landurbplan.2018.01.008 
Appendix 1: Examples of statement related to each CES

\begin{tabular}{ll}
\hline \multicolumn{1}{c}{ CES } & \multicolumn{1}{c}{ Examples of statement related to each CES } \\
\hline Recreation & I like to spend leisure time, play games and sports, walking, playing with kids etc. \\
Aesthetics & I consider the scenery beautiful \\
Sense of Place & I find my comfort zone here \\
Social Cohesion & Green spaces provide me the place to meet friends and near and dear ones. \\
Education and & I value gardens and parks because I learned about nature from here during my \\
Learning & student life \\
Mental Satisfaction & Green spaces make me feel better and provide relaxation \\
Inspiration & Green places inspire me for art and poetry \\
Religious and & I value these spaces because it provides elements for religious purposes \\
spiritual & \\
Natural Awareness & Green spaces it makes me aware of environment and conservation \\
Cultural Heritage & I value these sites because they are related to our culture and local history \\
\hline
\end{tabular}


Appendix 2: Personal information of the respondents

\begin{tabular}{lll}
\hline & $\begin{array}{l}\text { Number of the } \\
\text { respondents }\end{array}$ & $\begin{array}{l}\text { Percentage (\%) of } \\
\text { the respondents }\end{array}$ \\
\hline $\begin{array}{l}\text { Gender } \\
\text { Male }\end{array}$ & 214 & 52.8 \\
Female & 191 & 47.2 \\
& & \\
Income & 91 & 22.5 \\
$<25000$ BDT & \\
25000-75000 BDT & 181 & 44.7 \\
$75000-150000$ BDT & 69 & 17.0 \\
$>150000$ BDT & 64 & 15.8 \\
& & \\
Education & 55 & 13.6 \\
Never been to school & 38 & 9.4 \\
Primary School & 80 & 19.8 \\
Secondary School & 176 & 43.5 \\
Graduate & 56 & 13.8 \\
Post Graduate & & \\
Visiting Frequency & & 20.2 \\
Daily & 82 & 47.7 \\
Weekly & 193 & 19.0 \\
Monthly & 77 & 13.1 \\
Yearly or less & 53 & \\
\hline
\end{tabular}

${ }^{+} \mathrm{BDT}=$ Bangladeshi Taka; $1 \mathrm{USD}=84.95 \mathrm{BDT}$ 
Appendix 3: Bivariate correlations between CES variables across participants. The strength is shown through Pearson's r coefficient.

\begin{tabular}{|c|c|c|c|c|c|c|c|c|c|c|}
\hline & $\begin{array}{l}\text { Mental } \\
\text { Satisfaction }\end{array}$ & $\begin{array}{l}\text { Sense of } \\
\text { Place }\end{array}$ & Aesthetics & Recreation & $\begin{array}{l}\text { Education } \\
\text { and } \\
\text { Learning }\end{array}$ & $\begin{array}{l}\text { Social } \\
\text { Cohesion }\end{array}$ & $\begin{array}{l}\text { Religious } \\
\text { and } \\
\text { spiritual }\end{array}$ & $\begin{array}{l}\text { Natural } \\
\text { Awareness }\end{array}$ & $\begin{array}{l}\text { Cultural } \\
\text { Heritage }\end{array}$ & Inspiration \\
\hline Mental & 1 & & & & & & & & & \\
\hline Satisfaction & & & & & & & & & & \\
\hline Sense of Place & $0.52 *$ & 1 & & & & & & & & \\
\hline Aesthetic & $0.35^{*}$ & $0.49 *$ & 1 & & & & & & & \\
\hline Recreation & -0.05 & $-0.20^{*}$ & 0.06 & 1 & & & & & & \\
\hline $\begin{array}{l}\text { Education and } \\
\text { Learning }\end{array}$ & 0.008 & 0.008 & 0.05 & $0.41^{*}$ & 1 & & & & & \\
\hline Social Cohesion & -0.02 & -0.04 & -0.05 & $0.21 *$ & $0.36^{*}$ & 1 & & & & \\
\hline $\begin{array}{l}\text { Religious and } \\
\text { Spiritual }\end{array}$ & 0.07 & -0.02 & $-0.21^{*}$ & 0.07 & $0.16^{*}$ & $0.12 *$ & 1 & & & \\
\hline $\begin{array}{l}\text { Natural } \\
\text { Awareness }\end{array}$ & $0.14^{*}$ & 0.05 & -0.04 & $-0.11 *$ & $0.32 *$ & $0.17 *$ & $0.60 *$ & 1 & & \\
\hline Cultural Heritage & $0.18^{*}$ & 0.01 & -0.03 & 0.092 & $0.29 *$ & $0.18^{*}$ & $0.62 *$ & $0.87 *$ & 1 & \\
\hline Inspiration & $0.21 *$ & $0.20 *$ & 0.11 & $0.14 *$ & $0.26^{*}$ & $0.27 *$ & $0.22 *$ & $0.34 *$ & $0.33 *$ & 1 \\
\hline
\end{tabular}

$* p<0.01$ (2-sided). 
Appendix 4: Green spaces stated important for providing specific cultural ecosystem services.

\begin{tabular}{ll}
\hline Green spaces & Cultural ecosystem services \\
\hline Rooftop Gardens & $\begin{array}{l}\text { Aesthetics, mental satisfaction, natural awareness, recreation, and } \\
\text { education and learning }\end{array}$ \\
Recreation, mental satisfaction, sense of place, social cohesion, and \\
natural awareness \\
Aesthetic, natural awareness, mental satisfaction, social cohesion, and \\
Gardens & recreation \\
Field & Recreation, Natural Awareness, education and learning, natural awareness \\
Streetside greenery & and aesthetic \\
\hline
\end{tabular}

